\title{
EFFECT OF SALTING AND STORAGE ON CHEMICAL COMPOSITION OF SOME FISH SPECIES
}

Alsaban, W. A'; S. H Abou - El-Hawa, ${ }^{2}$; Manal. A. M Hassan ${ }^{2}$ and AbdEL-Rahman, M. A $^{2}$

1.Food\& Fish Technology Department, Faculty of Environmental Science and Marine Biology, Hadhramut University ,Yemen

2.Food Science \& Technology Department, Faculty of Agriculture, Assiut University, Egypt

\begin{abstract}
ABESTRACT
The effect of salting and storage for three months on chemical composition in whole and cleaned of three fish species namely: Bolti (Tilapia nilotica ), Karmout (Claries lazera) and Kannome (Mormyrus kannume) were studied.

The results show that moisture and protein contents of fresh Bolti were higher than Karmout and Kannome, while lipid and ash contents of fresh Kannome were higher than Karmout and Bolti.

Salting and storage processes decreased the moisture and protein contents, while ash content was increased in each of whole and cleaned three fish species. Meanwhile, lipid content was increased after 10 days salting in cleaned of three fish species, them decreased at the end of storage time. On the other hand, the results revealed that lipid content was increased during salting and storage in whole of three fish species.

The results reported that, such change in chemical composition during salting and storage in whole and cleaned of three fish species gave rise to recommend that salting of whole fish was better than cleaned fish.
\end{abstract}

\section{INTRODUCTION}

Fish is considered an important source of protein which has a great nutritional value and contain all the essential amino acids, which are very important for human health. It is also a satisfactory source of simple and compound lipids which contain a large amount of the essential fatty acids, and minerals especially phosphorus, magnesium, calcium, sodium, potassium, iron and copper (Zaitsev et al., 1969; Oyedapo et al., 2005 and Adeniyi et al., 2012).

Salting is a popular procedure for preserving fish. Salting methods are simple and involve salt crystals or brine. There are three types of salting of fish: dry salting, wet salting and combination of the two methods. Length of salting time as well as salt concentration depends on the expected final product. The theoretical foundation sodium chloride diffuses to the outside from muscles due to difference in osmotic pressure between the brine and fish muscle this process does not continue indefinitely: sodium and chlorine ions form a water binding complex with protein which itself exerts an osmotic pressure and eventually equilibrium is reached (Horner, 1997 and Bellagha et al., 2007).

Hernandez-Herrero (1997) found that after salting process of anchovy, the moisture content decreased from $75.5 \%$ to $54.0 \%$ on wet weight basis 
and the loss moisture content was accompanied by increases in the salt and ash contents. The same author reported that after salting process of anchovy the ash content increased from $1.6 \%$ to $21 \%$ of wet weight.

El-Sebaiy and Metwalli (1989) found that the crude protein content in fresh Bouri ( Mugil cephalus) decreased from $82.5 \%$ to $71.1 \%$ after salting and fermenting process. El- Sharnouby (1989) found that the crude protein in grey mullet decreased from $77.73 \%$ in fresh fish to $49.91-62.36 \%$ after 4 weeks salting.

Cha et al., (1983) found little differences in total lipids due to salt concentration and the time of salting within the same fish species. While Abou-El-Hawa et al., (1978) found that lipid content of fresh Bolti , Labes , Karmout and Kannome were $9.35 \%, 10.00 \%, 17.50 \%$ and $19.30 \%$ of dry weight, respectively, then decreased during salting and storage $4^{\circ} \mathrm{C}$ for 6 months to $8.45 \%, 9.05 \%, 15.45 \%$ and $16.70 \%$ of dry weight , respectively at the end of storage.

Badawy (1979) mentioned that lipid content of fresh (Tilapia nilotica), (Clarius lazera) and (Angulla vulgaris) were $9.13 \%, 18.12 \%$ and $58.67 \%$ of dry weight, respectively, then lipid content increased after 5 days salting to $10.29 \%, 19.85 \%$ and $60.09 \%$ of dry weight , respectively.

The brine concentration showed an important effect on the rate of diffusion in to the muscle and weight changes during the salting processing. Solute diffuses from the salting agent into fish muscle and water diffuses out of the fish, due to the differences in osmotic pressures between inter-cells and salting agent. Salt uptake depends on many factors including species, muscle type, fish size, fillet thickness, weight and composition, physiological state, salting method, brine concentration, fish-to-salt ratio and temperature (Raoult-Wack, 1994 and Gallart- Jornet et al., 2007).

The physicochemical changes of tilapia muscle during salting depended on the salting method and salting time (Chaijan, 2011). The biochemical processes that cause the changes in chemical and histological properties of the salted fish named ripening .The ripening of salted product begin with the breakdown of proteins and lipids by proteolytic and lipolytic enzymes. Generally, the quality of the salted fish depends on the quality and chemical composition of raw material. Freshness is an important parameter that affects the quality of salted cod during the salting process, as the freshest raw material gives the lowest overall yield and the lowest salt uptake (Vaskresensky, 1966 and Barat et al., 2006).

The objective of this study was to investigate the effect of salting and storage on chemical composition of three fish species, namely: Bolti (Tilapia nilotica), Karmout (Claries lazera) and Kannome (Marmyus kannome), and distinction between salting whole fish and salting cleaned fish knowing which of them is the best.

\section{MATERIALS AND METHODS}

\section{Materials}

The selected species of fish whole and cleaned used in this investigation were: Bolti (Tilapia nilotica), Karmout (Claries lazera) and 
Kannome (Mormyrus kannume). The previous fish samples were obtained as soon as possible after catching from local markets of Assiut Governorate and transferred directly to the laboratory. The average weight of individual fish was about 500 grams for Bolti, Kannome while the individual Karmout weight was 850 grams.

Technological treatment:

Salted fish species were prepared as follow

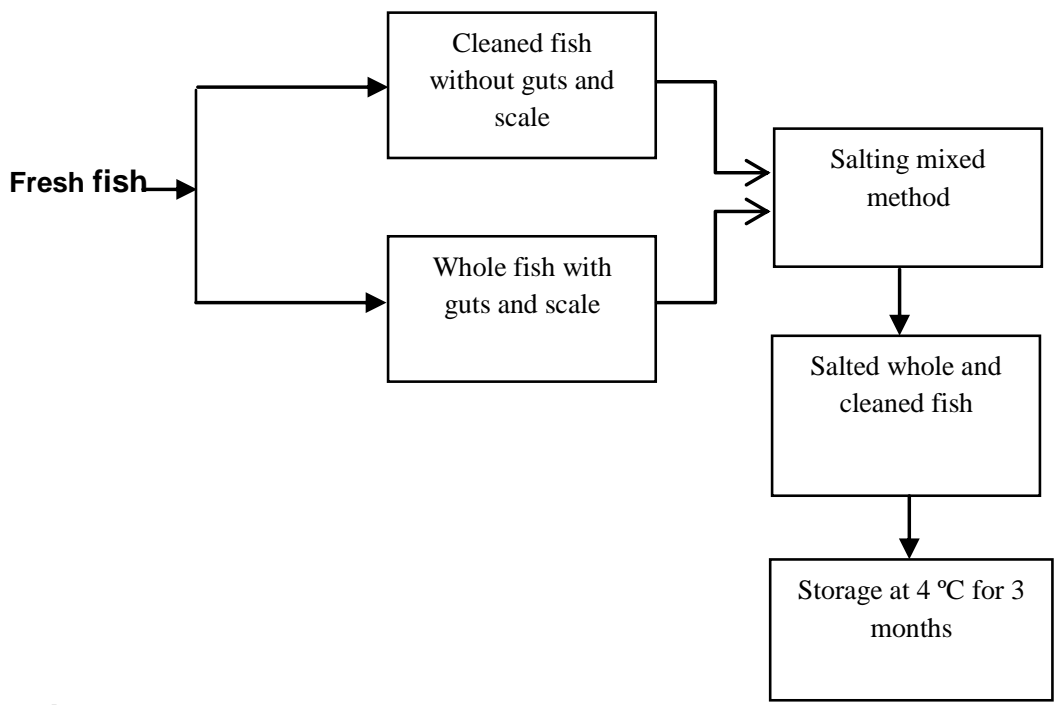

\section{Analytical Methods:}

Gross chemical composition: Moisture, protein and Ash contents were determined according to the methods of A.O.A.C (1994).

Lipid content was determined according to the method described by Folch et al., (1957).

\section{RESULTS AND DISCUSSION}

\section{Change in gross chemical during salting and storage.}

\section{Moisture content}

Results of the effect of salting and storage on moisture content in muscles of studied fish species are tabulated in Table (1). Moisture content of fresh Bolti was higher than Karmout and Kannome where reached to $77.13 \%$, $76.35 \%$ and $74.65 \%$ on wet weight; respectively. During salting and storage the moisture content was decreased in both whole and cleaned of fish species, where moisture content of whole is higher than that of cleaned of fish species. Where reached of whole and cleaned Bolti to $66.44 \%$ and $66.22 \%$ on wet weight; respectively at the end of storage time. While whole and cleaned Karmout reached to $64.35 \%$ and $63.92 \%$ on wet weight; respectively at the end of storage time. Whole and cleaned Kannome reached to $63.80 \%$ and $63.65 \%$ on wet weight; respectively at the end storage time. Because in decrease moisture content high osmotic pressure 
lead to diffuses salt into the fish tissues, but at the same time water moves by osmosis from the fish at a high speed into the surrounding brine and the fish declines in weight (Voskresensky, 1965). The results are in accordance with those of Badawy (1979); Hernandez-Herrero (1997) and Ahmed et al., (2010).

Table (1): The effect of salting and storage at $4^{\circ} \mathrm{C}$ on moisture content in muscles of fish species (\% on wet weight basis)

\begin{tabular}{|l|c|c|c|c|c|c|}
\hline \multirow{2}{*}{ Treatments } & \multicolumn{2}{|c|}{ Bolti } & \multicolumn{2}{c|}{ Karmout } & \multicolumn{2}{c|}{ Kannome } \\
\cline { 2 - 7 } & Whole & cleaned & whole & cleaned & whole & cleaned \\
\hline Fresh & 77.13 & 77.13 & 76.35 & 76.35 & 74.65 & 74.65 \\
\hline After 10 days salting & 71.70 & 70.30 & 69.95 & 68.57 & 68.25 & 67.65 \\
\hline After 20 days salting & 70.99 & 70.26 & 68.95 & 67.75 & 67.65 & 66.90 \\
\hline After 30 days salting & 69.63 & 69.19 & 67.75 & 66.70 & 66.38 & 65.15 \\
\hline Storage 1 month & 68.29 & 67.90 & 66.79 & 65.42 & 65.50 & 64.60 \\
\hline Storage 2 months & 67.63 & 67.15 & 65.78 & 64.77 & 64.86 & 64.25 \\
\hline Storage 3 months & 66.44 & 66.22 & 64.35 & 63.92 & 63.80 & 63.65 \\
\hline
\end{tabular}

${ }^{*}$ Each value given in table is a mean of three determination

\section{Protein content}

Results of the effect of salting and storage on protein content in muscles of studied fish species are presented in Table (2). Protein content of fresh Bolti was higher than that of Karmout and Kannome with values: $81.81 \%, 71.71 \%$ and $64.67 \%$ on dry weight; respectively. During salting and storage the protein content decreased in each of whole and cleaned of fish species. Where the protein content of whole was higher than cleaned fish, it reached of whole and cleaned Bolti to $46.25 \%$ and $45.38 \%$ on dry weight; respectively at the end of storage time. While whole and cleaned Karmout reached to $45.27 \%$ and $42.96 \%$ on dry weight; respectively at the end of storage time. Also whole and cleaned Kannome reached to $44.14 \%$ and $42.17 \%$ on dry weight; respectively at the end of storage time. As a result of decreasing in protein content salt penetrates the tissue, it alters the colloidal properties of the proteins and changes the nature of the water/protein relationship (Zaitzev et al., 1969). This finding can be explained as a result of the denaturation of both sacoplasmic and myofibrillar proteins due to the effect heavy salting on fish muscle. These results are in accordance with ElSharnouby (1989) and Ahmed et al., (2010)

Table (2):The effect of salting and storage at $4^{\circ} \mathrm{C}$ on protein content in muscles of fish species (\% on dry weight basis) ${ }^{*}$.

\begin{tabular}{|l|c|c|c|c|c|c|}
\hline \multirow{2}{*}{ Treatments } & \multicolumn{2}{|c|}{ Bolti } & \multicolumn{2}{c|}{ Karmout } & \multicolumn{2}{c|}{ Kannome } \\
\cline { 2 - 7 } & whole & cleaned & whole & cleaned & whole & cleaned \\
\hline Fresh & 81.81 & 81.81 & 71.71 & 71.71 & 64.67 & 64.67 \\
\hline After 10 days salting & 64.17 & 61.08 & 56.24 & 53.20 & 53.10 & 51.56 \\
\hline After 20 days salting & 59.39 & 57.30 & 54.11 & 51.63 & 51.81 & 50.15 \\
\hline After 30 days salting & 56.27 & 55.21 & 51.94 & 49.85 & 49.67 & 47.78 \\
\hline Storage 1 month & 52.79 & 51.37 & 49.98 & 47.43 & 48.12 & 46.33 \\
\hline Storage 2 months & 48.69 & 46.67 & 47.93 & 44.53 & 46.67 & 45.17 \\
\hline Storage 3 months & 46.25 & 45.38 & 45.27 & 42.96 & 44.14 & 42.17 \\
\hline
\end{tabular}

${ }^{*}$ Each value given in table is a mean of three determination 


\section{Lipid content}

Results of the effect of salting and storage on lipid content in muscles of studied fish species are shown in Table (3). Lipid content of fresh Kannome was higher than Karmout and Bolti, where reached to $22.09 \%$, $19.20 \%$ and $9.79 \%$ on dry weight; respectively. After 10 days salting, the lipid content was increased in cleaned fish, where the lipid content of Kannome, Karmout and Bolti reached to $22.38 \%, 19.60 \%$ and $9.90 \%$ on dry weight; respectively. The increase in lipid, content may be attributed to breakdown of lipoprotein during salting and liberation of lipids to tissue muscles (Voskresensky, 1966). After that the lipid content decreased at the end of storage time in cleaned Kannome, Karmout and Bolti, where reached to $19.67 \%, 16.91 \%$ and $8.35 \%$ on dry weight; respectively. The decreasing in lipid content, may be attributed to their insolubility in water, which diffusion throughout the cell walls to the brine solution and the hydrolysis of triglycerides and phospholipids, which is catalyzed by lipases and phospholipases and release of free fatty acids that is soluble in water, then leaching into the drip (Voskresensky, 1966; Aman and Shehata, 1978 and AlHabib and Al-aswad, 1985). Lipid content of whole Kannome, Karmout and Bolti during salting and storage increased, reached to $24.89 \%, 22.22 \%$ and $13.20 \%$ of dry weight; respectively at the end of storage time. The increase in lipid content of whole fish species during salting and storage may be due to its migration lipid from viscera to tissue during preparation and storage and breaking lipoprotein during salting and liberalization lipids to tissue muscles (Voskresensky, 1966; Abou-El-Hawa, 1970 and Fouad, 1976). The results are in agreement with Badawy (1979); El-Sharnouby (1989) and Ahmed et al.,(2010).

Table (3): The effect of salting and storage at $4^{\circ} \mathrm{C}$ on lipid content in muscles of fish species (\% on dry weight basis).

\begin{tabular}{|l|c|c|c|c|c|c|}
\hline \multirow{2}{*}{ Treatments } & \multicolumn{2}{|c|}{ Bolti } & \multicolumn{2}{c|}{ Karmout } & \multicolumn{2}{c|}{ Kannome } \\
\cline { 2 - 7 } & whole & cleaned & whole & cleaned & whole & cleaned \\
\hline Fresh & 9.79 & 9.79 & 19.20 & 19.20 & 22.09 & 22.09 \\
\hline After 10 days salting & 12.01 & 9.90 & 21.13 & 19.60 & 23.78 & 22.38 \\
\hline After 20 days salting & 12.50 & 9.75 & 21.64 & 19.03 & 24.17 & 21.84 \\
\hline After 30 days salting & 12.97 & 9.41 & 21.95 & 18.41 & 24.42 & 20.72 \\
\hline Storage 1 month & 13.09 & 8.97 & 21.98 & 17.70 & 24.55 & 20.40 \\
\hline Storage 2 months & 13.16 & 8.65 & 22.06 & 17.17 & 24.84 & 20.14 \\
\hline Storage 3 months & 13.20 & 8.35 & 22.22 & 16.91 & 24.89 & 19.67 \\
\hline
\end{tabular}

${ }^{*}$ Each value given in table is a mean of three determination.

\section{Ash content}

Results of the effect of salting and storage on ash content in muscles of studied fish species presented in Table (4). Ash content of fresh Kannome was higher than that of Karmout and Bolti where reached to $6.75 \%, 5.65 \%$ and $4.90 \%$ on dry weight; respectively. During salting and storage the ash content was increased in each of whole and cleaned of fish species, where ash content in cleaned was higher than whole fish species, reached of whole 
and cleaned Kannome to $21.49 \%$ and $28.75 \%$ of dry weight; respectively at the end of storage time. While whole and cleaned Karmout reached to $23.87 \%$ and $31.54 \%$ on dry weight; respectively at the end of storage time. Also whole and cleaned Bolti reached to $30.31 \%$ and $36.20 \%$ on dry weight; respectively at the end storage time. The increasing in ash content during salting period may be due to effect of extracted lipid which helps to create a crusted surface on each dried fish (Mohammed, 2007) and effect of ground bones and scales in dried meat, also the presence of residues from salt during preparation of samples for analysis and this consequently lead to increase the ash content. These results were agreement with HernandezHerrero (1997) and Ahmed et al. (2010).

Table (4): The effect of salting and storage at $4^{\circ} \mathrm{C}$ on ash content in muscles of fish species (\% on dry weight basis)

\begin{tabular}{|l|c|c|c|c|c|c|}
\hline \multirow{2}{*}{ Treatments } & \multicolumn{2}{|c|}{ Bolti } & \multicolumn{2}{c|}{ Karmout } & \multicolumn{2}{c|}{ Kannome } \\
\cline { 2 - 7 } & whole & cleaned & whole & cleaned & whole & cleaned \\
\hline Fresh & 4.90 & 4.90 & 5.65 & 5.65 & 6.75 & 6.75 \\
\hline After 10 days salting & 10.11 & 16.70 & 12.01 & 17.12 & 12.03 & 15.27 \\
\hline After 20 days salting & 16.89 & 21.32 & 14.04 & 19.53 & 13.20 & 17.49 \\
\hline After 30 days salting & 19.30 & 24.18 & 16.34 & 22.31 & 15.53 & 21.52 \\
\hline Storage 1 month & 23.21 & 28.97 & 18.58 & 25.82 & 17.25 & 23.50 \\
\hline Storage 2 months & 27.46 & 33.27 & 20.89 & 28.38 & 18.67 & 25.06 \\
\hline Storage 3 months & 30.31 & 36.20 & 23.87 & 31.54 & 21.49 & 28.75 \\
\hline
\end{tabular}

${ }^{*}$ Each value given in table is a mean of three determination.

In conclusion, from the above- motioned results it is quite clear that salting and storage of three studies fish species caused changes in chemical composition. Meanwhile the results revealed that the salting of whole fish was better than cleaned fish.

\section{REFERENCES}

Abou-El-Hawa, S. H. (1970): Changes in phospholipids during processing and storage of dried Vobla. Ph.D. Thesis, Astrakhan, U.S.S.R. (In Russian), (C.F. Badawy, R. M. (1979): Chemical and Technological Studies on Lipid of Some Local Smoked fish. M.S Thesis in Food Technology, Fac. of Agric., Assiut Univ).

Abou-El-Hawa, S. H.; Hammadi, K. A. and Youssef, K. E. (1978): Effect of salting and storage on the lipid fractions of certain Nile fish species. Assiut J. Agri. Sci. 8 (2):201- 215.

Adeniyi, S. A.; Orjiekwe, C.L.; Ehiagbonare, J. E. and Josiah, S. J. (2012): Nutritional Composition of Three Different Fishes (Clarias gariepinus, Malapterurus electricus and Tilapia guineensis) Pakistan J. Nutri. 11 (9): 793-797.

Ahmed, E. O.; Ali, M. E. and Hamed, A. A. (2010): Quality Changes of Salted Kass (Hydrocynus forskalii) During Storage at Ambient Temperature $\left(37 \pm 1^{\circ} \mathrm{C}\right)$. Pakistan J. Nutri. 9 (9): 877-881 
Al-Habib, F. M. and Al-aswad, M. B. (1985): Some chemical and physical changes in some frozen IRAQI fish. Zanco, 3, 4:35-50.

Aman, M.E. and Shehata, A. A. (1978): Effect of prolonged frozen storage and after heat treatment on lipid change in the muscle of sheat Fish. J. Alex. Agric. Res, 26, 1:45.

AOAC, Association of Official Analytical Chemistry, (1994): Official methods of analysis of the Association of Official Analytical Chemists, Vols. I \& II, Association of Analytical Chemists, Arlington, pp: 1298.

Badawy, R. M. (1979): Chemical and Technological Studies on Lipid of Some Local Smoked fish. M.S Thesis in Food Technology, Fac. of Agric., Assiut Univ.

Barat, J. M.; Gallart-Jornet, L.; André, A.; Akse, A.; Carlehog, M. and Skjerdal, O. T. (2006): Influence of cod freshness on the salting, drying and desalting stages. J. Food Engi. 73, 9-19.

Bellagha, S.; Sahli, A.; Farhat, A.; Kechaou, N. and Glenza, N. (2007). Studies on salting and drying of sardine (Sardinella aurita): Experimental kinetics and modeling. J. Food Eng., 78: 947-952.

Chaijan, M. (2011): Physicochemical changes of tilapia (Oreochromis niloticus) muscle during salting. Food Chemis. 12: 1201-1210.

Cha,Y. J. ; Cho, S. Y. ; Oh, K .S. and Lee, E . H. (1983): Studies on the processing of low salt fermented sea foods.2- The taste compounds of low salt fermented sardine. Bull-Korean fish Soc.16 (2):140-146.

El-Sebaiy, L.A. and Metwalli, S. M. (1989): Change in chemical characteristics and lipid composition of salted fermented bouri fish muscle (Mugil cephalus). Food chem., 31(1) 41-50.

El-Sharnouby, S. A. (1989): Chemical and Technological Studies on Roles enzyme determining the quality of Salted and cured .Ph.D. Thesis Fac. of Agric., Alex. Univ., Egypt.

Folch,J . ; Lees, M. and Sloanestanley, G. H. (1957): A simple method for the isolation and purification of total lipid from animal tissue, J. Biol. chemis. 226-497.

Fouad, A. A. (1976): Chemical and technological studies on phospholipids in nile Bolti fish. Ph. D. Thesis. Fac. of Agric., Assiut. Univ., Egypt.

Gallart-Jornet, L.; Barat, J. M.; Rustad, T.; Erikson, U.; Escriche, I. and Fito, P. (2007): A comparative study of brine salting of Atlantic cod (Gadus morhua) and Atlantic salmon (Salmo salar). J .Food Engi. 79, 261-270.

Hernandez- Herrero, M. M. (1997): Influencia de la calidad higienicadel boqueron( Engraulis encrasicholus var. Mediterraneas) Thesis Doctoral. Universitat Autonona de Barcelona, Barcelona, Spain. (C.F. Awad, A. A. M. (1999): Physical and chemical studies on some factors affecting the quality of salted anchovy. Thesis .ph. D. Fac. of Agri. Fayoum. Cairo univ.).

Horner, W. F. A. (1997): Salting. In: Fish Processing Technology: Preservation of Fish, Curing. GM Hall (ed), Chapman \& Hall Publishers. UK, pp: 32-72.

Mohammed, M. O. (2007): A guide for tradition preservation methods of fish curing. Sud J. Stnds. Metrol. 1: 1-33. 
Oyedapo, A. F.; Mosunmola, O. A.; Oluwayemisi, E. A. and Ameenat, A. R.( 2005): Flesh Yield Waste Yield, Proximate and Mineral Composition of Four Commercial Waste African Freshwater Food Fishes , J. Animal and Veterinary Advances 4(10): 848-851.

Raoult-Wack, A. L. (1994): Recent advances in the osmotic dehydration of foods. Trends in Food Sci. Tech. 5, 255-260.

Voskresensky, N.A. (1965). Salting of herring. Fish as Food Borgstrom, G. ed. Vol III. New York: Academic Press.

Voskresensky, N. A. (1966): Technology of salting, smoking and drying fish, Peshipromizdat, Moscow (In Russian).

Zaitsev, V. I; Kisevetteo , I. ; Logunov, L . ; Mokarora, T.; Minder, L. and Podsevalov, V. (1969): Fish Curing and Processing. Translated from Russian by A. Demerindol. Mir. Puplishers, Moscow.

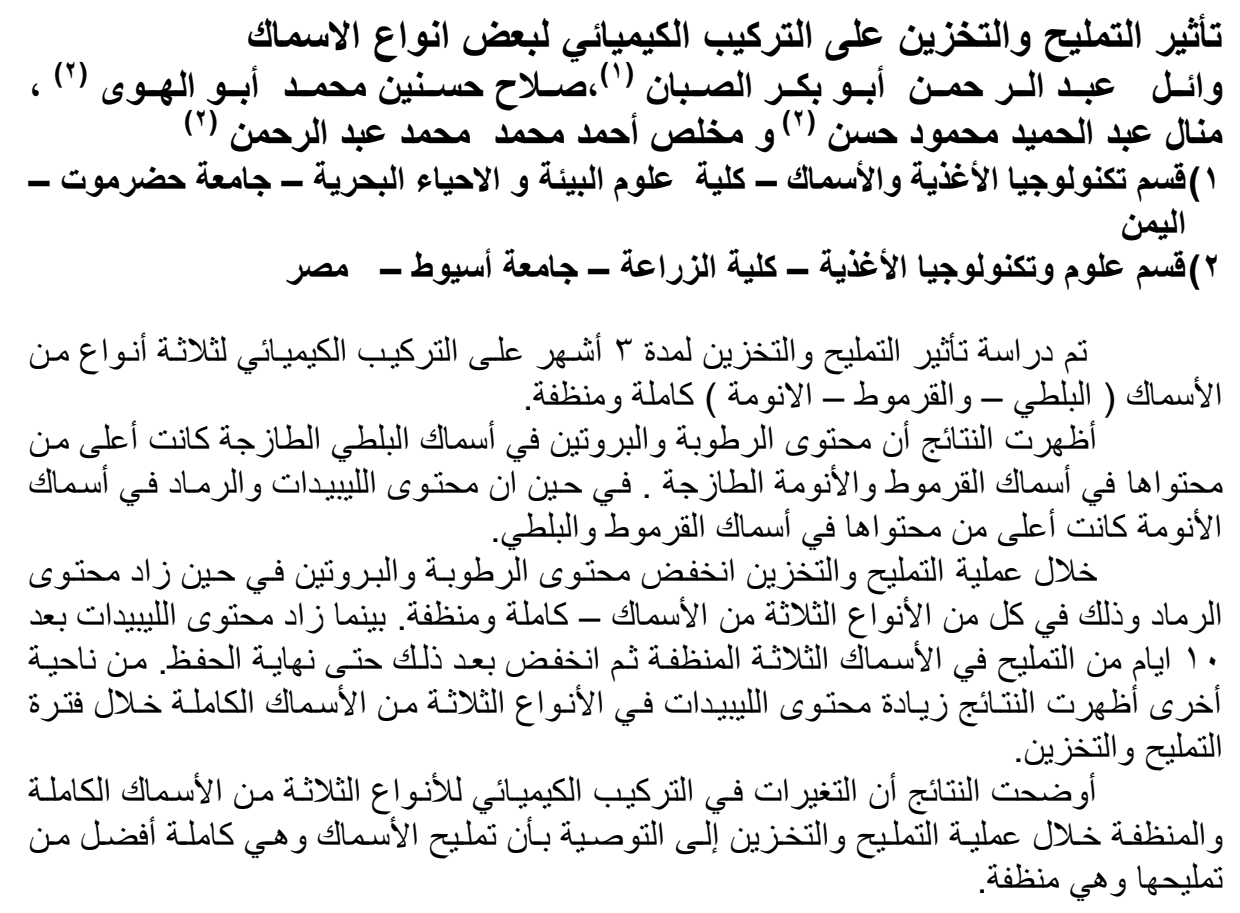

